Abstracta Iranica

Revue bibliographique pour le domaine irano-aryen

Volume 28 | 2007

Comptes rendus des publications de 2005

\title{
Zākānī-nāme. Tehrān, Zavvār, 1384/2005, 358 p.
}

\section{Michele Bernardini}

\section{Q OpenEdition}

\section{Journals}

\section{Édition électronique}

URL : http://journals.openedition.org/abstractairanica/20741

DOI : 10.4000/abstractairanica.20741

ISSN : 1961-960X

\section{Éditeur :}

CNRS (UMR 7528 Mondes iraniens et indiens), Éditions de l'IFRI

\section{Édition imprimée}

Date de publication : 15 mai 2007

ISSN : 0240-8910

\section{Référence électronique}

Michele Bernardini, « Zākāni-nāme. Tehrān, Zavvār, 1384/2005, 358 p. », Abstracta Iranica [En ligne], Volume 28 | 2007, document 335, mis en ligne le 18 septembre 2007, consulté le 25 septembre 2020 URL : http://journals.openedition.org/abstractairanica/20741 ; DOI : https://doi.org/10.4000/ abstractairanica. 20741

Ce document a été généré automatiquement le 25 septembre 2020.

Tous droits réservés 


\title{
Zākānì-nāme. Tehrān, Zavvār, $1384 / 2005,358 \mathrm{p}$.
}

\author{
Michele Bernardini
}

1 Ce volume, consacré à 'Obeyd Zākānī, fournit une nouvelle contribution sur sa biographie et sur son style littéraire. Après une longue introduction historique consacrée à l'époque de l'auteur, où sont traitées les périodes injuide, jalayride et mozaffaride (cette dernière traitée surtout à partir d'un ouvrage célèbre de Mahmūd Kotobī, paru dans les années 1950), l'A. analyse la copieuse production littéraire de Zākānī. Il la partage en deux parties distinctes : l'une, "sérieuse » (jeddī) et l'autre, «facétieuse » (hazali). En ce qui concerne cette première catégorie, il annonce vouloir se limiter à fournir quelques indications sommaires pour se consacrer principalement aux ouvrages "facétieux». À propos de ces derniers, il précise qu'il ne s'agit pas d'ouvrages superficiels où est exaltée la sottise, mais qu'il s'agit plutôt de textes d'une haute valeur artistique; par ailleurs, il remarque que Zākānī fut un des principaux interprètes de «l'esprit iranien ». Ceci dit, l'A. insère l'œuvre de Zākānī dans une perspective comparative où il cite Machiavel et Confucius. Cette partie inclut un paragraphe sur Zākānī et la foi islamique. Une section intéressante de ce chapitre est dédiée à la société de l'époque de Zākānī, telle qu'elle apparaît dans ses ouvrages et aux attitudes psychologiques des individus dans son temps. Cette section s'attache aux concepts tels que celui du $H^{w}$ od-bozorgbinin (la mégalomanie) qui caractérisait, selon l'A., l'activité des souverains de l'époque. De plus, la famille, la femme et les enfants sont objets d'une attention particulière dans cet ouvrage, et l'A. voit dans le traitement de la famille l'un des indicateurs sociologiques les plus importants qui apparaissent dans les œuvres de cet érudit médiéval. Une sélection de textes, cités d'après des éditions existantes, termine le volume.

2 Il est dommage que la production littéraire «sérieuse » ait été écartée de l'analyse présentée par l'auteur. Le Zākānī-humoriste avait déjà été abondamment traité dans les études antérieures, que l'on retrouve d'ailleurs ici plus ou moins reproduites. Ceci n'est pas le cas de sa production littéraire «sérieuse " qui ne devrait pas être aussi radicalement isolée du restant de son œuvre. Cette remarque implique aussi 
l'importance de la prise en considération du rapport complexe existant entre Zākānī et son illustre contemporain Ḥâfez, ce dernier auteur n'ayant été mentionné que marginalement dans une seule page de ce Zākāni-nāme.

INDEX

Thèmes : 11.1.1. Littérature persane classique

\section{AUTEURS}

MICHELE BERNARDINI

Università di Napoli « L’Orientale » 